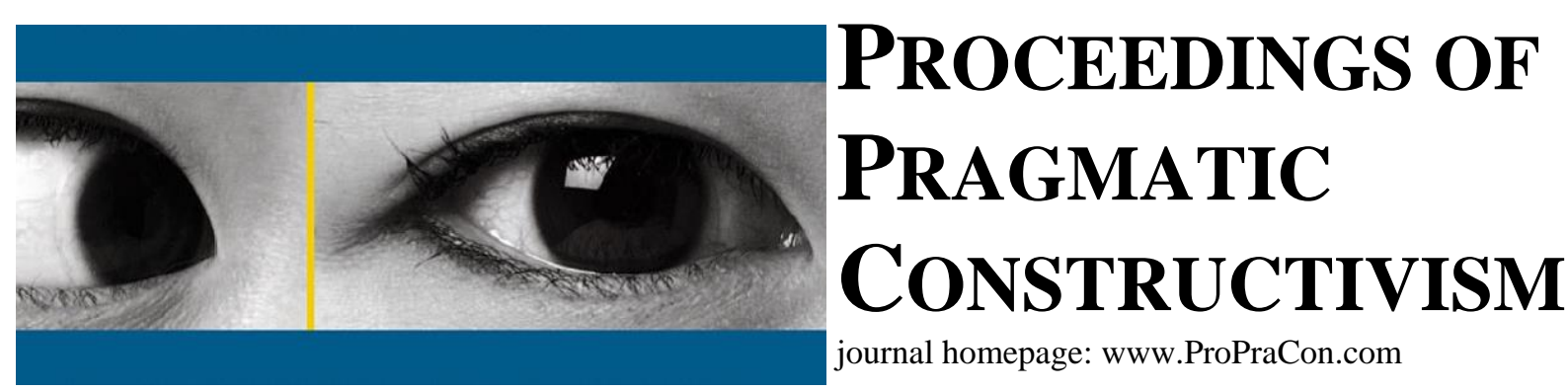

\title{
Highlighting the complex interrelationship between the concepts of trust and control
}

\author{
Peter Beusch \\ Senior Lecturer in Management Accounting \\ University of Gothenburg; School of Business, Economics and Law \\ Vasagatan, 40530 Göteborg, Sweden; peter.beusch@handels.gu.se
}

\begin{abstract}
This paper presents the area of management control and trust in an inter-organizational setting with an attempt to offer a fresh perspective on the complex relationship between and different understandings of the two concepts of trust and control. This is done with help of two case studies in a cross-cultural setting and involving five multinational companies that were involved in two large acquisitions. Obviously, different actor groups' cultural and educational heritage has brought with it that dissimilar opinions exist on the subject of mainly system-based versus inter-personal based trust.

The paper first demonstrates that trust and control can mean different but also the same things to different people, depending very much on the logic and values applied but also depending on if the actors were motivated more intrinsically or extrinsically. Further, what impact certain control mechanisms, or the lack thereof, have on individual's behavior is outlined. The paper also reveals that it is difficult to find the right balance between diverse types of control and trust as time went on after the acquisitions. The main reason for this is that actors with different socio-cultural heritage use different references regarding trust and control and put unlike emphasis on what should be focused on, what should be counted, and what should be accounted for. Trust and control can mean almost identical things but the cases illustrate that, from a rhetorical and convincing point of view, system trust appears to be stronger in certain settings than inter-personal trust, as it, to particular actors, provides the impression of being in control. The contrary is true in other settings, where having 'facts and figures' and 'a whole bunch 'of accounting systems and accounting techniques not automatically mean to be in control, thus leaving more room for the use and appreciation of interpersonal trust.
\end{abstract}

Keywords: Trust, control, concepts, management control, mergers, acquisitions. 
Highlighting the complex interrelationship

between

the concepts of trust and control

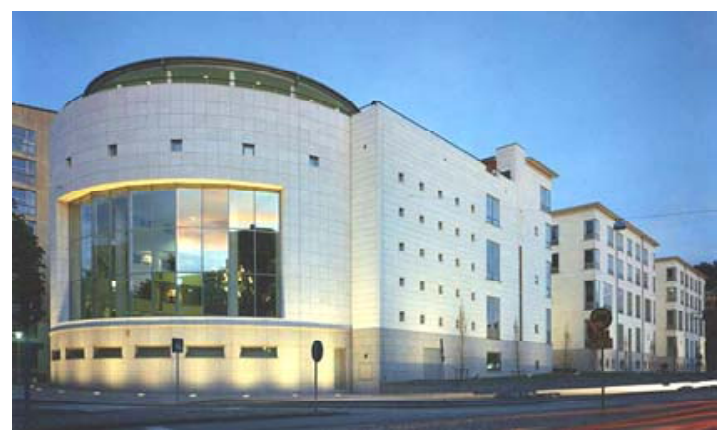

Peter Beusch

The Actor-Reality Perspective in a Global Economy,

Second conference in Pisa, Italy

$25 \& 26$ October2012

\section{Goals with this presentation}

1. Present some results regarding interrelationship of trust and control from case studies (one more study is to include in order to update the context). $\rightarrow$ Industry + Insurance \& Banking

2. Use your knowledge to examine my way of how I connected my results to the actor-reality perspective and to get critique/new input! 


\section{Background}

1. Concept of trust \& control important elements in organizations (when coordinating, organizing \& managing things)

2. Many definitions, many ways to look at it, many different concepts (individually and together)

3. Increased attention also within accounting, especially management accounting (Baldvinsdottir et al. 2011)

4. Within MA it is often used as a way to express some sort of control/or the lack of it....

5. But different views are applied (being sustitute or being complementary), but also others, e.g:

$\rightarrow$ role changes over time

$\rightarrow$ relationship changes over time

$\rightarrow$ all this is different in different contexts (socio-culturally dependent as we have different preferences \& values

$\rightarrow$ impact on way we look at both concepts and what they mean/should mean)

\section{Trust becomes more important because:}

1. Increased flexibility $\rightarrow$ workforce, processes, speed of change, globalization, etc.) unables monitoring to same extent (technological abilities increase as well?)

2. More and more intangible resources $\rightarrow$ (service industry etc.) $\rightarrow$ tacit knowledge important (tnot as easy, the asset moves with the holder)

3. Increased complexity makes the cognitive distance bigger $\rightarrow$ more difficult to monitor and control!

4. Transaction cost become to high $\rightarrow$ therfore trust (rather rational thought...) 


\section{Missing is:}

1. More theoretical but also empirical input regarding the content of and relationship between these two concepts

2. Contextual understanding

3. How this relates to Management control systems but also actors working with these systems

4. If concepts are connected to some sort of theoretical view applied of researcher?

5. If certain methodologies have particular strength or weaknesses when applied in certain settings?

\section{My assumptions and key points}

(in the article)

1. Growth with help of M\&As, compared to organic, has a great disadvantage due to non-familiarity of new partner $\rightarrow$ less trust in (un-known) systems and people

2. In different contexts with dissimilar preferences for MC-structures and MCpractices the interplay between trust and control is different (more technocratic alternatively more socio-idelogical)

3. People based trust (often the result of face to face knowledge, but nothing in print) and system based trust (face-less contact, but normally in print, often referred to as control) have different strength \& weaknesses in different situations (due to different topoi...)

4. In order to enable good cooperation and integration it is essential to understand this particular interplay in its context (topoi can help understand...) 


\section{Supposed contribution with article}

1. Add a more sociological view to the relatively mainstream biased litterature within management control and M\&As

2. Illustrate the relationship between control and trust during "MC integration attempts" mad after M\&As (in the making or construction)

3. Combine different 'trust' and control framworks that combine actors really experineced reality

4. Pragmatically: it wil lhelp actors in real life situations to understand the concepts

\section{Because (rational):}

Management control as well as trust are both complex theoretical concepts that draw on a large variety of theoretical traditions and rest on a number of assumptions. Therefore, we cannot simply blackbox the area of management control or trust but need to examine them in detail and together. 


\section{Intrinsic versus extrinsic:}

- Difference between appropriate behaviour (March \& Olson (1998)

$\rightarrow$ the logic of appropriateness

1. Formal rules (accounting rules) but also required accounting techniques used) $\rightarrow$ external \& extrinsic motivation

2. Accepted norms (on the half way to intrinsic)

3. Shared beliefs (totally intrinsic)

\section{Tacit knowledge}

- Mangement Control is mostly a tacit knowledge

(most issues within this area are actually not

visible $\rightarrow$ only the output or results in form of reports)

$\rightarrow$ increased complexity means that more and more issues need to be solved with help of other means than monitoring and control (informal control needed!) $\rightarrow$ post-bureacucracy or even something more modern?

$\rightarrow$ transaction costs get too high

$\rightarrow$ cannot see the forest due to all the trees 


\section{$\underline{\text { Trust and control as opposites }}$}

- Control uses threat of enforcement of agreement

- When appearing at the same time (to do something in order to achieve more control $\rightarrow$ not to do it is then "Trust"

\section{Theoretical influences on MC}

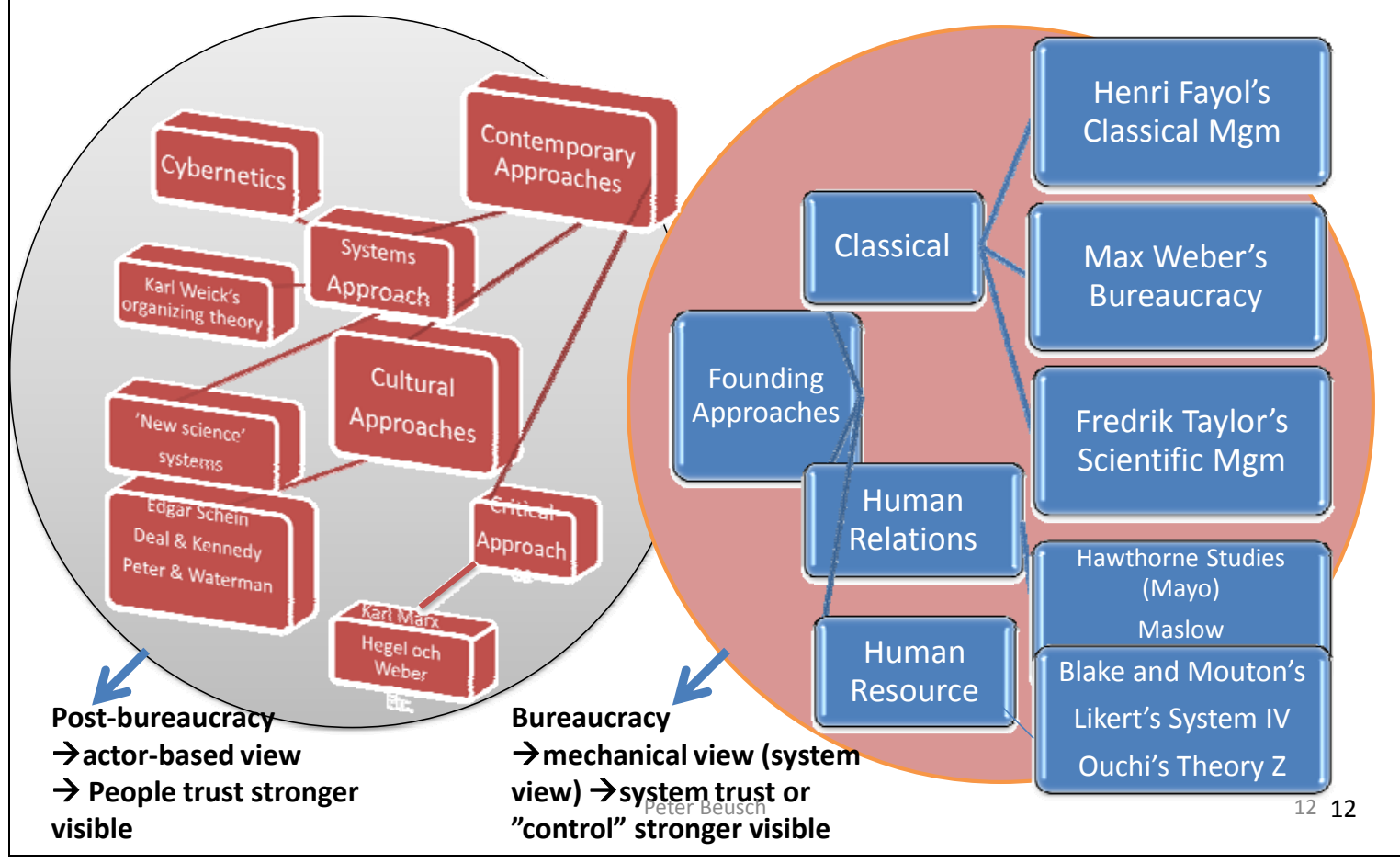




\section{Usable control frameworks}

- Management control $\rightarrow$ many definitons but normally it includes:

"the exercise of power (influence) in order to secure sufficient resources, and mobilize and orchestrade individual and collective action towards (more or less) given ends" (Alvesson \& Kärreman, 2004)

- Technocratic $\leftarrow \rightarrow$ socio-ideological control (Alvesson \& Kärreman, 2004)

$\rightarrow$ bureaucratic-technocratic control systems are non-obvious sources of socio-ideological control

$\rightarrow$ often too strong emphasis on either or orientation in control litterature

(e.g. structural control vs. cultural control ; informal control and formal control $\rightarrow$ but culture can replace structure or only influence, etc....)

$\rightarrow$ Taylorism or managerialism; when managerial activity attempts to control behaviour: "construct work contexts where workers discretion is minimized, to the extent thet htey only can do the prescribed thing with a minimum of effort and movement" (p.425) $\rightarrow$ (direct control)

$\rightarrow$ MC-practices targeting minds: "through norms, emotions, beliefs and values are intended to affect behaviour indirectly" (p. 425) $\rightarrow$ normative, cultural-ideological, concertive $(\rightarrow$ indirect control)

\section{Control issues:}

1. Different control types during different periods: Control rhetorics change from normative to rational forms (Barley \& Kunda, 1992)

2. Dominant types in differnt organizations (all sorts of combinations with different strength depending on different issues (cultural, societal, ideological, managerial)

3. Malmi \& Brown (2008)

4. ......

5. $\quad \cdots . .$.

\begin{tabular}{|c|c|c|c|c|c|c|}
\hline \multicolumn{7}{|c|}{ Cultural Controls } \\
\hline \multicolumn{3}{|c|}{ Clans } & \multicolumn{2}{|c|}{ Values } & \multicolumn{2}{|c|}{ Symbols } \\
\hline \multicolumn{2}{|c|}{ Planning } & \multicolumn{4}{|c|}{ Cybernetic Controls } & \multirow[b]{2}{*}{$\begin{array}{c}\text { Reward and } \\
\text { Compensation }\end{array}$} \\
\hline $\begin{array}{c}\text { Long } \\
\text { range } \\
\text { planning }\end{array}$ & $\begin{array}{c}\text { Action } \\
\text { planning }\end{array}$ & Budgets & $\begin{array}{c}\text { Financial } \\
\text { Measurement } \\
\text { Systems }\end{array}$ & $\begin{array}{l}\text { Non Financial } \\
\text { Measurement } \\
\text { Systems }\end{array}$ & $\begin{array}{c}\text { Hybrid } \\
\text { Measurement } \\
\text { Systems }\end{array}$ & \\
\hline \multicolumn{7}{|c|}{ Administrative Controls } \\
\hline Govern & ance Struct: & & Organisati & Structure & Policies: & nd Procedures \\
\hline
\end{tabular}

\section{Questions}

1) Relationship between and contextual influence on these control types?

2) How is trust included here? 


\section{Trust issues:}

Zucker's generic trust-producing mechanisms (Zucker, L.G. (1986), "Production of trust: institutional sources of economic structure, 1840-1920", Research in Organizational Behavior, Vol. 8, pp. 53-111.)

- process-based trust $\rightarrow$ depends on past and future exchanges

- character-based trust $\rightarrow$ relies on features such as ethnicity, age and gender

- institution-based trust $\rightarrow$ "formal mechanisms are used to provide trust that does not rest on personal characteristics or past history of exchange" (p. 61).

- Trust and control not opposites!

- Trust as informal control or people control $\leftarrow \rightarrow$ trust in systems and structures (accounting techniques, etc.)

\section{Other trust issues}

- Competency based trust:

- Goodwill-based trust:

- Generic categories of trust (Rousseau et al., 1998)

- Deterrence-based trust (based on the threats of punishment if consistent behavior is not uphold)

- Calculus-based trust is based on rational choice where willingness to trust is limited to specific financial exchange and where trust is present because the alternative is more costly

- Relational trust results from continual interaction over time between trustor and trustee

- Institutional-based trust is founded on institutional factors such as legal regulations, social networks and shared norms that can facilitate in establishing both calculus-based and relational trust 


\section{$\underline{\text { Trust \& Control }}$}

Tomkins framwork

Most reffered to/used framwork within the area of Accounting (Baldvinsdottir et al., 2011)

Trust defined (does a definition help?):

1) "a blief or expectation about a trustee....

2) a behavioural intention that reflects a reliance on the trustee adn involves vulnerability and uncertainty on the part of the trustor" (Vélez et al., 2008)

$\rightarrow$ the trustor is a human (individual or group)

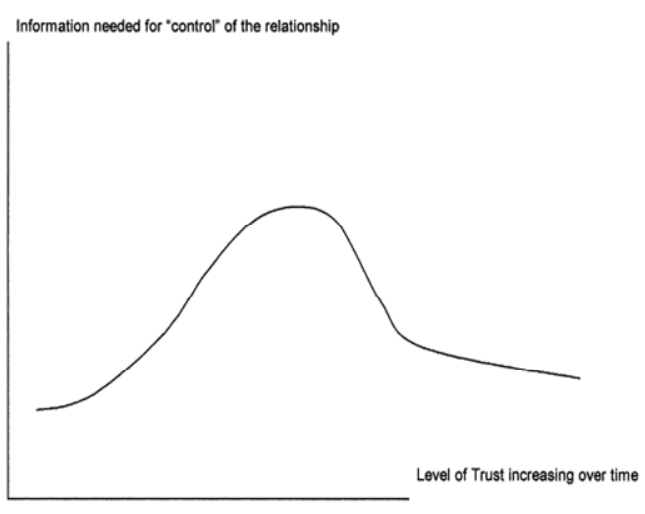

C. Tomkins / Accounting, Organizations and Society 26 (2001) 161191

$\rightarrow$ the trustee may be things as well as people and their systems

$\rightarrow$ "When an actor rests positive expectations on structural influences on the embedded other, we speak of control", on the other hand, "when an actor rests positive expectations on an assumption of benevolent agency on the part of the other, we speak of trust (Möllering, 2005: 287-288).

\section{Trust \& MCS \& M\&As (inter-organizationall}

- MCSs and trust are both sources of confidence that a partner will cooperate (Das \& Teng, 1998)

- Trust is created by using MCS together (inter-organizational) to coordinate new and complex tasks (Vélez et al., 2008)

- Only informal control can built trust (Das \& Teng, 2001; Inkpen \& Curral, 2004) $\rightarrow$ not action or results control (according to the concept of Merchant \& Van der Stede, 2003)

- Action and results control can also build trust since they provide evidence with a greater appearance of objectivity (Vélez et al. 2008). 


\section{Change in control types:}

- From written documents, scripts, protocols to $\rightarrow$ increasing emphasis on identity, culture, ideology and other unobtrusive (Perrow, 1986) forms of control

- From the symbolic $\rightarrow$ the imaginary (Styre, 2008)

- $\quad$ From the register of language $\rightarrow$ the register of images (Styre, 2008)

- Rather stable and fixed $\rightarrow$ more flexible and adaptable (environment)

- From rather predictable and determined work practices to $\rightarrow$ ad-hoc solution and creativity, interesting and challenging work assignments for employees (Styre, 2008)

- Control is a value-neutral mechanism that regulates organizations (Tannenbaum, 1968)

- Weber's (1999, p.100) ideal type of organizations do not allow "personal motives or temper influencing conduct, free of arbitrariness and unpredictability".

- In bureaucratic control, inside and outside transparency is important, but this is not the same within post-bureaucratic organizations, where new forms of control are emerging (Styre, 2008) .....(trust needed?)

- From technocratic control $\rightarrow$ normative control (Alvesson, 2004)

- From technocratic control ("attempts to directly control worker behavior") socio-ideological control ("attempts to control worker beliefs") $\rightarrow$ Kärreman \& Alvesson, 2004, p. 152)

\section{Combine with this day's discussion on the Actor-based perspective!}

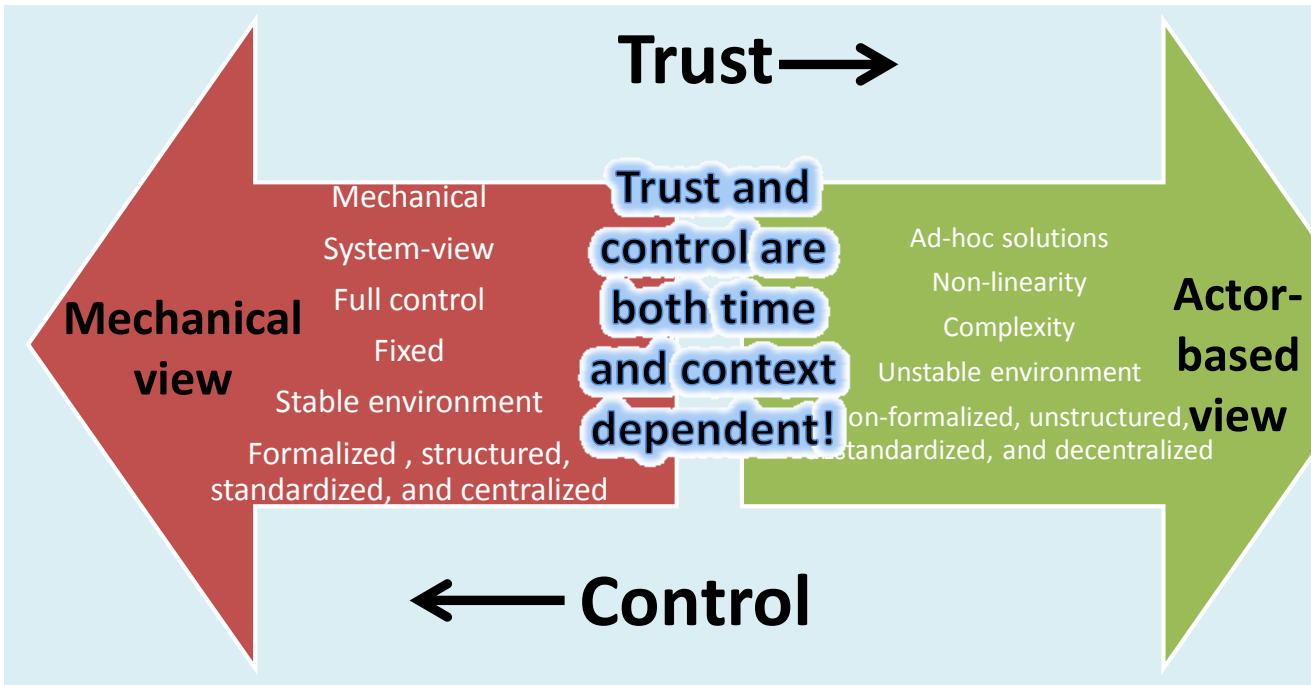




\section{The study: setting \& time frame!}

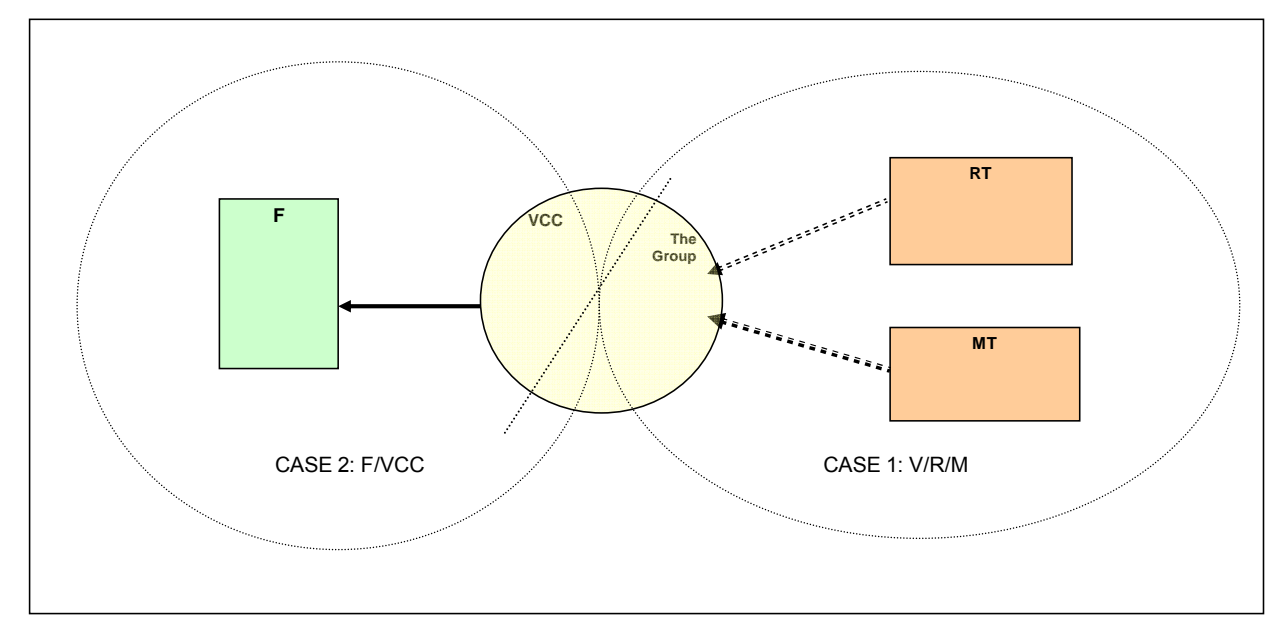

\section{Outlining the context}

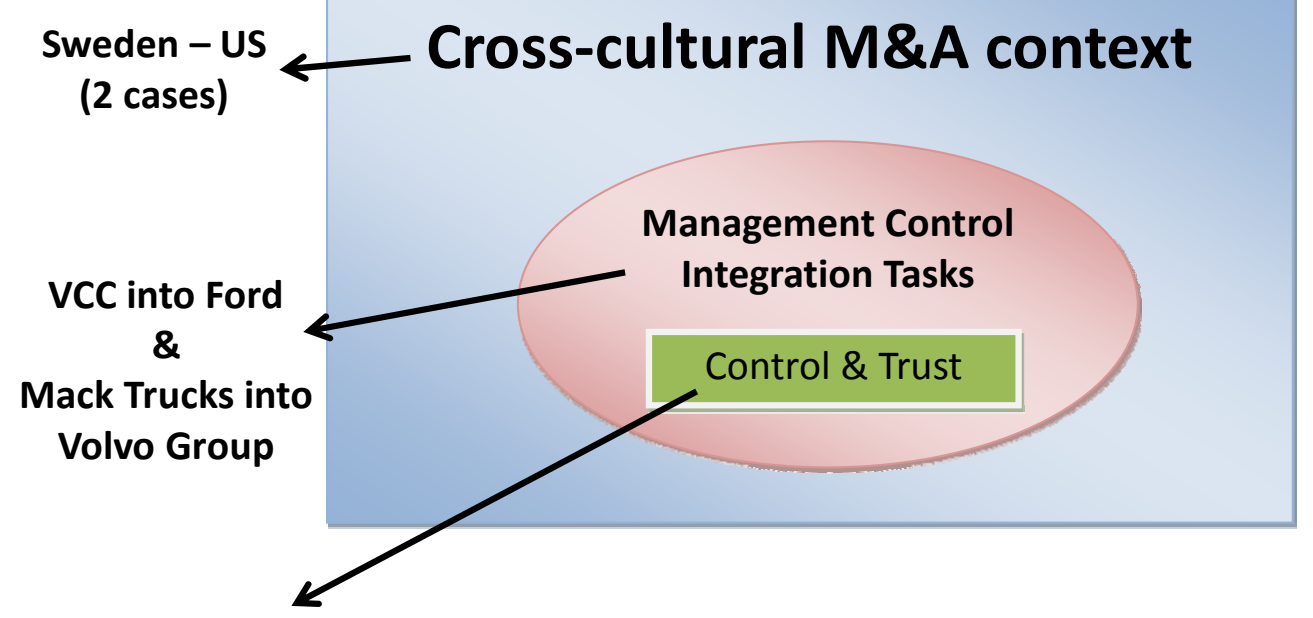

Analyze the interaction /

relationship/ change /

similarities \& differences) 


\section{The vocabulary in my thesis:}

\section{MC ideology (and rhetorics)}

$\rightarrow$ indicating that I included "values, ideals, and understandings about a particular part of social reality which justify certain commitments and actions" (Alvesson \& Kärreman, 2004, p. 426)

$\rightarrow$ the Mainstream approach $\leftarrow \rightarrow$ the Swedish Volvo approach! (=both include such ingrediences)

$\rightarrow$ Ideology can be seen as control (Czarniawska-Joerges, 1988)

$\rightarrow$ Management control through ideology (ideas) rather than through instructions (Beckérus \& Edström et al., 1988)

\section{Assumptions....}

- Ford \& VCC $\rightarrow$ different perceptions of "trust", "relationships"

- Sweden-US $\rightarrow$ collectivism vs. individualism

- Sweden - US $\rightarrow$ more actor-based vs. system based control framework (trust is then defined differently and used for 


\section{The Reality Model and theoretical perspectives}

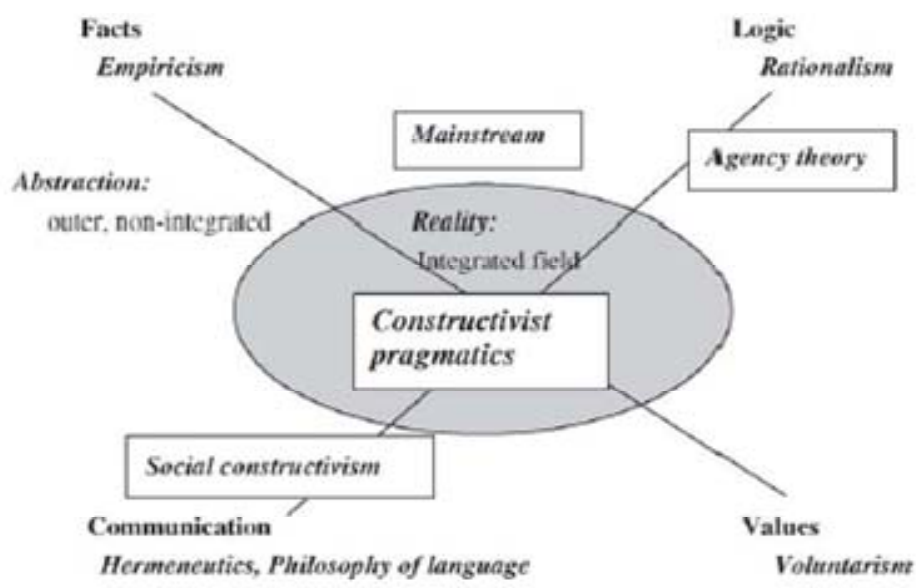

Fig. 1. Reality and the theoretical perspectives.

\section{The Reality Model and Practice}

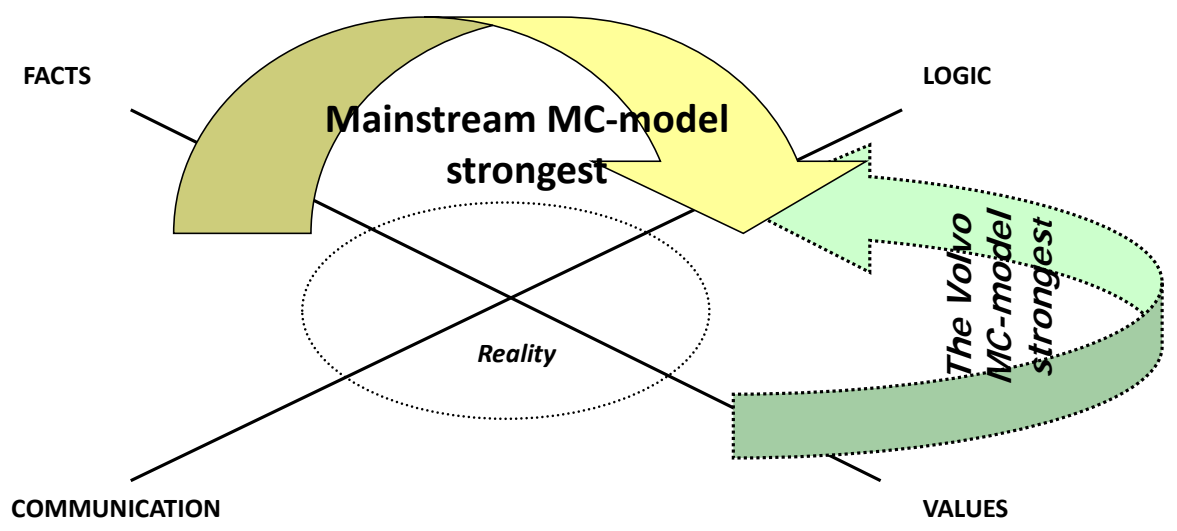




\section{Typical characteristics of the two MC-models (1)}

\begin{tabular}{|c|c|c|}
\hline Characteristics & The Group MC-WAY & The Mainstream MC-WAY \\
\hline Control philosophy: & $\begin{array}{l}\text {-Special \& rather unique } \\
\text {-Typically Swedish }\end{array}$ & $\begin{array}{c}\text {-Mainstream } \\
\text { - Anglo-Saxon/Continental/French }\end{array}$ \\
\hline Object of Control: & -Ends (output) strongly & -Means (behavior) strongly \\
\hline Type of Control: & $\begin{array}{c}\text {-Strongly cultural control } \\
\text { (Shared norms of performance and philosophy of } \\
\text { management) }\end{array}$ & $\begin{array}{l}\text {-Strongly formalized control } \\
\text { (Company manuals and formal performance reports) }\end{array}$ \\
\hline Feeling/control tool: & -Business feeling at most places & $\begin{array}{l}\text {-Budgeting at most places, } \\
-\mathrm{HQ} \text { is thinking business }\end{array}$ \\
\hline Management control focus: & $\begin{array}{l}\text {-Externally (customers) } \\
\text { and internally (less) }\end{array}$ & $\begin{array}{c}\text {-Mainly internally } \\
\text { (systems and processes) }\end{array}$ \\
\hline $\begin{array}{l}\text { Control motto (e.g. Sox } \\
\text { applications): }\end{array}$ & $\begin{array}{l}\text {-Reduce depth but increase width } \\
\text { (balanced view) } \\
\text {-Generalist }\end{array}$ & $\begin{array}{l}\text {-Go into the depths as much as possible } \\
\text { (Experts) }\end{array}$ \\
\hline Key technique used is: & $\begin{array}{l}\text {-Gross-profit and Bottom-line accounting } \\
\text {-Drives 'cost consciousness' backwards }\end{array}$ & $\begin{array}{l}\text {-Contribution-margin thinking } \\
\text {-Cost control 'evidence' from the beginning }\end{array}$ \\
\hline Standard costing policy: & $\begin{array}{l}\text {-Get as many costs out to the customers as possible } \\
\text {-Rather too much accounted for than too little }\end{array}$ & $\begin{array}{c}\text {-'Actual' standards needed, precisely } \\
\text {-Rather know what the lowest needed contribution is } \\
\text { than anything else }\end{array}$ \\
\hline Control content: & -Appropriate clear & -As clear as possible \\
\hline
\end{tabular}

\section{Typical characteristics of the two MC- models (2)}

\begin{tabular}{|c|c|c|}
\hline Characteristics & The Group MC-WAY & The Mainstream MC-WAY \\
\hline Focus/work way: & -Cross-functional, process & -Functional, hierarchical \\
\hline $\begin{array}{l}\text { Main driver for } \\
\text { business/projects/pr } \\
\text { oduct development: }\end{array}$ & $\begin{array}{c}\text {-Work ways and processes necessary to achieve core } \\
\text { characteristics }\end{array}$ & $\begin{array}{c}\text {-Finance and IT -tools, system technical possibilities } \\
\text { within organization }\end{array}$ \\
\hline Business Control as: & $\begin{array}{l}\text {-Steering function } \\
\text {-Forward driving activities mostly } \\
\quad \text {-Future oriented }\end{array}$ & $\begin{array}{l}\text {-Control function } \\
\text {-Strongly backwards looking } \\
\text {-Past oriented }\end{array}$ \\
\hline MCS and Brand: & $\begin{array}{l}\text {-Should generate Premium Price Products } \\
\text { (Premium-brand) } \\
\text {-Major goal is to achieve as high price as possible }\end{array}$ & $\begin{array}{l}\text {-Is generating Price Conscious Products } \\
\text { (Mass-market) } \\
\text {-Focus on producing as cheaply as possible }\end{array}$ \\
\hline $\begin{array}{l}\text { Status/function of } \\
\text { Finance }\end{array}$ & $\begin{array}{l}\text {-Administrative \& Supportive \& then Determining } \\
\text {-Sell solutions to business areas }\end{array}$ & $\begin{array}{l}\text {-Key role in determining what projects to invest in } \\
\text {-Force business areas to do certain things }\end{array}$ \\
\hline Information needed: & -De-centralized (business areas \& units) & -Centralized (Headquarter) \\
\hline Power lies mostly in: & -Actors/Behavior & -Systems/Formalized \\
\hline Decision-making is: & $\begin{array}{l}\text {-Focus on consensus } \\
\text {-Done close to customers } \\
\text {-Focus on the content of the discussions (means) }\end{array}$ & $\begin{array}{l}\text {-Hierarchical, management levels } \\
\text {-Done at Headquarter and high levels mostly } \\
\text {-Focus on the decisions (ends) }\end{array}$ \\
\hline Information must be: & $\begin{array}{c}\text {-Easily accessible \& understandable \& situation specific } \\
\text { everywhere }\end{array}$ & $\begin{array}{l}\text {-Aggregated \& precise and same format and formal } \\
\text { in order to deliver upwards }\end{array}$ \\
\hline The key actors are: & -Financial "business partners" & -Financial "professionals" \\
\hline
\end{tabular}




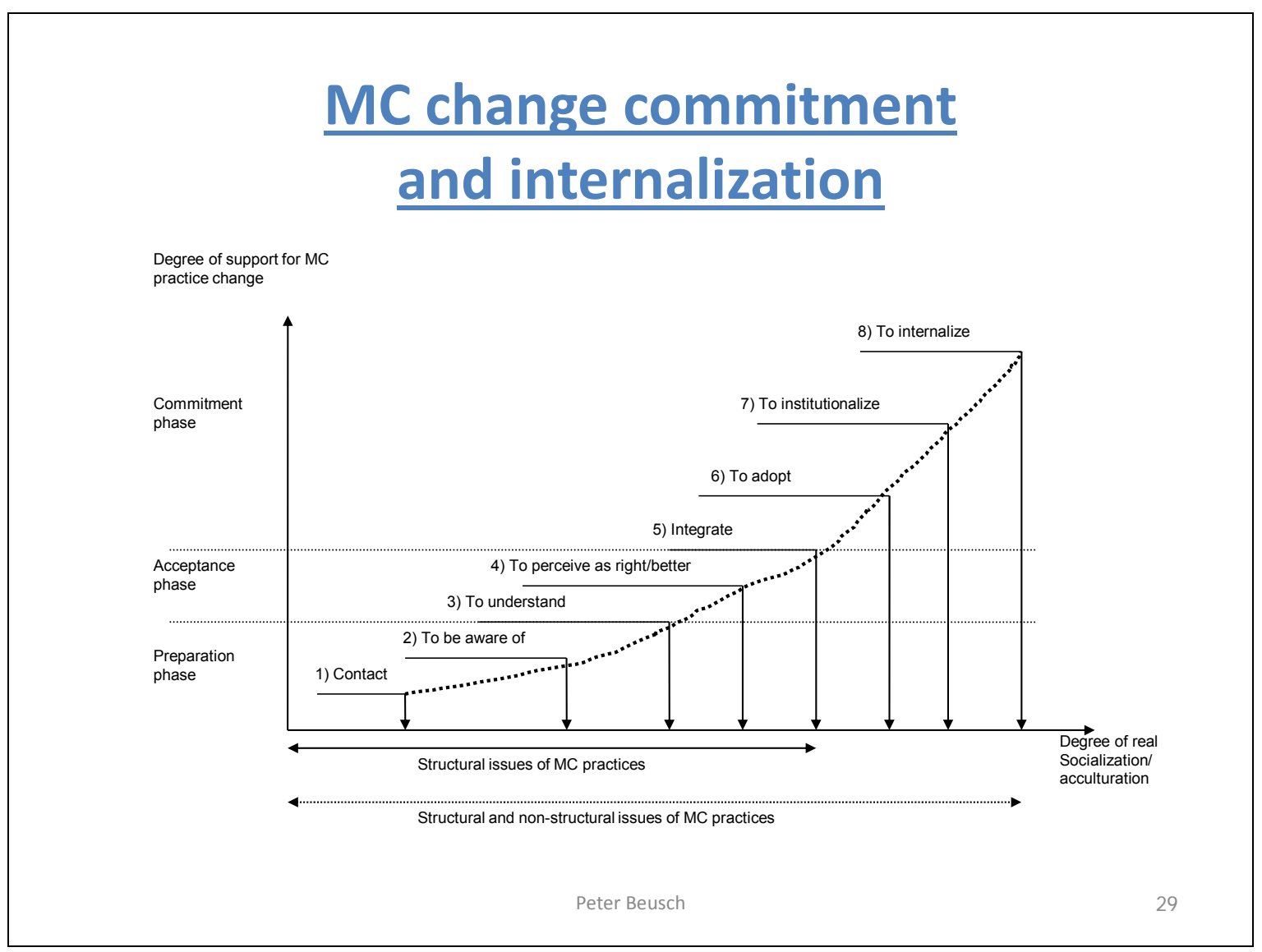




\section{References}

Alvesson, M. 2004. Knowledge Work and Knowledge-intensive Firms. Oxford/New York, NY: Oxford University Press.

Bachmann, R., \& Zaheer, A. 2006. Handbook of Trust Research. Cheltenham: Edward Elgar.

Baldvinsdottir, G., Hagberg, A., Johansson, I.-L., Jonäll, K., \& Marton, J. 2011. Accounting research and trust: a literature review. Qualitative Research in Accounting \& Management, 8(4): 382-424.

Baliga, B. R., \& Jaeger, A. M. 1984. Multinational corporations: control systems and delegation issues. Journal of International Business Studies, 21(4): 25-40.

Beusch, P. 2007. Contradicting Management Control Ideologies - A study of Integration Processes Following Crossborder Acquisitions of Large Multinationals. Gothenburg: BAS Publishing.

Bijlsma-Frankema, K., \& Costa, A. C. 2005. Understanding the trust-control nexus. International Sociology, 20(3): 259-282.

Blomqvist, K. 1997. The many faces of trust. Scandinavian journal of management, 13(3): 271-286.

Buono, A. F., \& Bowditch, J. L. 2003. The Human Side of Mergers and Acquisitions: Managing Collisions Between People, Cultures, and Organizations. Washington, DC: BeardBooks.

Cartwright, S., \& Cooper, C. L. 1996. Managing Mergers, Acquisitions and Strategic Alliances: Integrating People and Cultures (2nd ed.). Oxford/Boston, MA: Butterworth-Heinemann.

Chenhall, R. H. 2003. Management control systems design within its organizational context: findings from contingency-based research and directions for the future. Accounting, Organizations and Society, 28(2-3): 127168.

Cooper, D. J., \& Hopper, T. 2007. Critical theorising in management accounting research. In C. S. Chapman, A. G. Hopwood, \& M. D. Shields (Eds.), Handbook of Management Accounting Research: 207-245. London: Elsevier.

Das, T. K., \& Teng, B.-S. 2001. Trust, control, and risk in strategic alliances: an integrated framework. Organization Studies, 22(2): 251-283.

Deutsch, M. 1958. Trust and suspicion. Journal of Conflict Resolution, 2(4): 265-279.

DiMaggio, P., \& Powell, W. W. 1983. The iron cage revisited: institutional isomorphism and collective rationality in organizational fields. American Sociological Review, 48(2): 147-160.

Free, C. 2008. Walking the talk? Supply chain accounting and trust among UK supermarkets and suppliers. Accounting, Organizations and Society, 33(6): 629-662.

Giddens, A. 1990. The Constitution of Society. Cambridge: Polity Press.

Inkpen, A. C., \& Currall, S. C. 2004. The coevolution of trust, control, and learning in joint ventures. Organization Science, 15(5): 586-599.

Kärreman, D., \& Alvesson, M. 2004. Cages in tandem: management control, social identity, and identification in a knowledge-intensive firm. Organization, 11(1): 149-175.

Lewicki, R. J., \& Bunker, B. B. 1996. Developing and maintaining trust in work relationships. In R. M. Kramer, \& T. R. Tyler (Eds.), Trust in Organizations: 114-139. Thousand Oaks, CA: Sage.

Lewicki, R. J., Tomlinson, E. C., \& Gillespie, N. 2006. Models of interpersonal trust development: theoretical approaches, empirical evidence, and future directions. Journal of Management, 32(6): 991-1022.

Lewis, J. D., \& Weigert, A. 1985a. Trust as a social reality. Social Forces, 63(4): 967-985.

Lewis, J. D., \& Weigert, A. J. 1985b. Social atomism, holism, and trust. The Sociological Quarterly, 26(4): $455-471$.

Luhmann, N. 1979. Trust and Power: Two Works by Niklas Luhmann. Chichester: Wiley.

Luhmann, N. 1988. Familiarity, confidence, trust: problems and alternatives. In D. Gambetta (Ed.), Trust: Making and Breaking Cooperative Relations: 94-107. Oxford: Basil Blackwell.

Merchant, K. A. 1998. Modern Management Control Systems: Text and Cases. Upper Saddle River, NJ: Prentice Hall.

Merchant, K. A., \& Van der Stede, W. A. 2007. Management Control Systems: Performance Measurement, Evaluation and Incentives (2nd ed.). Upper Saddle River, NJ: Prentice Hall.

Mintzberg, H. 1979. The Structuring of Organizations. Upper Saddle River, NJ: Prentice-Hall.

Murphy, G. 2002. The Big Book of Concepts. Cambridge, MA: MIT Press.

Nooteboom, B. 2002. Trust: Forms, Foundations, Functions, Failures and Figures. Cheltenham: Edward Elgar.

Nørreklit, H., Nørreklit, L., \& Mitchell, F. 2010. Towards a paradigmatic foundation for accounting practice. Accounting, Auditing \& Accountability Journal, 23(6): 733-758.

Nørreklit, L., Nørreklit, H., \& Israelsen, P. 2006. The validity of management control topoi: towards constructivist pragmatism. Management Accounting Research, 17(1): 42-71.

Ouchi, W. G. 1977. The relationship between organizational structure and organizational control. Administrative Science Quarterly, 22(1): 95-112. 
Ouchi, W. G. 1979. A conceptual framework for the design of organizational control mechanisms. Management Science, 25(9): 833-848.

Perrow, C., Wilensky, H. L., \& Reiss, A. J. 1986. Complex organizations: A Critical Essay (3rd ed.). New York, NY: Random House.

Reed, M. I. 2001. Organization, trust and control: a realist analysis. Organization Studies, 22(2): 201-228.

Rousseau, D. M., Sitkin, S. B., Burt, R. S., \& Camerer, C. 1998. Not so different after all: a cross-discipline view of trust. Academy of Management Review, 23(3): 393-404.

Schein, L. 2001. Managing Culture in Mergers and Acquisitions. New York, NY: The Board.

Seal, W., Berry, A., \& Cullen, J. 2004. Disembedding the supply chain: institutionalized reflexivity and inter-firm accounting. Accounting, Organizations and Society, 29(1): 73-92.

Searle, J. R. 1995. The Construction of Social Reality. New York, NY: The Free Press.

Shapiro, D. L., Sheppard, B. H., \& Cheraskin, L. 1992. Business on a handshake. Negotiation Journal, 8(4): 365-377.

Sitkin, S. B., \& George, E. 2005. Managerial trust-building through the use of legitimating formal and informal control mechanisms. International Sociology, 20(3): 307-338.

Smith, E., \& Medin, D. 1981. Categories and Concepts. Cambridge, MA: Harvard University Press.

Stahl, G., Kremershof, I., \& Larsson, R. 2004. Trust dynamics in merges and acquisitions: a case study survey: INSEAD Working Papers Series.

Styhre, A. 2008. Management control in bureaucratic and postbureaucratic organizations: a Lacanian perspective. Group \& Organization Management, 33(6): 635-656.

Tannenbaum, A. S. 1968. Control in Organizations. New York, NY: McGraw-Hill.

Tomkins, C. 2001. Interdependencies, trust and information in relationships, alliances and networks. Accounting, Organizations and Society, 26(2): 161-191.

Vélez, M. L., Sánchez, J. M., \& Álvarez-Dardet, C. 2008. Management control systems as inter-organizational trust builders in evolving relationships: evidence from a longitudinal case study. Accounting, Organizations and Society, 33(7): 968-994.

Vosselman, E. G., \& van der Meer-Kooistra, J. 2009. Accounting for control and trust building in interfirm transactional relationships. Accounting, Organizations and Society, 34(2): 267-283.

Weibel, A. 2007. Formal control and trustworthiness: shall the twain never meet? Group \& Organization Management, 32(4): 500-517.

Yazdifar, H., Zaman, M., Tsamenyi, M., \& Askarany, D. 2008. Management accounting change in a subsidiary organisation. Critical Perspectives on Accounting, 19(3): 404-430.

Zucker, L. G. 1968. Production of trust: institutional sources of economic structure, 1840-1920. In B. M. Staw, \& L. L. Cummings (Eds.), Research in Organizational Behavior, Vol. 8: 53-111. Greenwich, CT: JAI Press. 